\title{
Erythromycin and clarithromycin attenuate cytokine-induced endothelin-1 expression in human bronchial epithelial cells
}

\author{
H. Takizawa*, M. Desaki*, T. Ohtoshi*, S. Kawasaki*, T. Kohyama*, M. Sato*, \\ J. Nakajima**, M. Yanagisawa+, K. Ito*
}

\begin{abstract}
Erythromycin and clarithromycin attenuate cytokine-induced endothelin-1 expression in human bronchial epithelial cells. H. Takizawa, M. Desaki, T. Ohtoshi, S. Kawasaki, T. Kohyama, M. Sato, J. Nakajima, M. Yanagisawa, K. Ito. CERS Journals Ltd 1998.

ABSTRACT: Erythromycin and its fourteen-member macrolide analogues have attracted attention for their efficacy in bronchial asthma. However, their mechanisms of action remain unclear. We evaluated the effects of the macrolide antibiotics on endothelin-1 (ET-1) expression in normal and transformed human bronchial epithelial cells, one of the sources of this potent bronchoconstrictor important in the pathogenesis of asthma.

Human bronchial epithelial cells were obtained from the resected bronchi, and the effect of several antimicrobial and antiasthmatic drugs on the production and messenger ribonucleic acid (mRNA) levels of ET-1 was evaluated. Bronchoepithelial cells were also isolated from the mucosa of asthmatic patients under fibreoptic bronchoscopy, and the modulating effects of the drugs were studied.

Erythromycin and clarithromycin uniquely suppressed mRNA levels as well as the release of ET-1 at therapeutic and non-cytotoxic concentrations (percentage inhibition of ET-1 protein release: $26.4 \pm 5.22 \%$ and $31.2 \pm 7.45 \%$, respectively, at $10^{-6} \mathrm{M}$ ). Furthermore, erythromycin and clarithromycin inhibited ET-1 expression in bronchoepithelial cells from patients with chronic, stable asthma. A glucocorticosteroid, dexamethasone, also inhibited ET-1 expression. In contrast, theophylline, salbutamol and FK506 had no effect on ET-1 production.

Our findings demonstrated that these fourteen-member macrolide antibiotics had an inhibitory effect on endothelin-1 expression in human bronchial epithelial cells. Moreover, this new mode of action may have some relevance to their clinical efficacy in bronchial asthma.
\end{abstract}

Eur Respir J 1998; 12: 57-63.
*Depts of Medicine \& Physical Therapy, and $* *$ Thoracic Surgery, University of Tokyo, School of Medicine, Hongo, Bunkyo-ku, Tokyo, Japan. +Howard Hughes Medical Institute, University of Texas, Southwestern Medical Center, Dallas, TX, USA.

Correspondence: H. Takizawa

Dept of Medicine \& Physical Therapy

University of Tokyo

School of Medicine

7-3-1 Hongo

Bunkyo-ku

Tokyo 113

Japan

Fax: 81338155954

Keywords: Airway epithelial cells endothelin

erythromycin

Received: September 241997

Accepted after revision April 141998

This work was supported in part by grants from The Japanese Ministry of Welfare, The Japanese Ministry of Education, Science and Culture, and The Manabe Medical Foundation.
Endothelin-1 (ET-1), a prototype of the endothelin family [1], is a potent bronchoconstrictive peptide that is believed to play an important role in the pathogenesis of bronchial asthma [2]. There is an increase of endothelin-1 in bronchoalveolar lavage fluid from patients with asthma [3], and its immunoreactivity is increased in the airway epithelium from patients with asthma [4]. It has also been shown that ET-1 levels decreased as the clinical disease severity declined by treatment $[3,4]$. Recent experiments with animal models of asthma [5] showed that endothelin receptor antagonists significantly suppressed allergic airway inflammation as well as late-phase asthmatic responses characteristic of chronic, persistent asthma. Airway epithelial cells have been considered to be important sources of this potent bronchoconstrictive agent [6-8], and therefore, their modulation may lead to the clinical amelioration of asthma.

Erythromycin, a macrolide antibiotic, has been reported to be effective as one of the choices for asthma treatment, especially for severe, intractable, or steroid-dependent asthma $[9,10]$. Erythromycin and its relative compound, roxithromycin, reduce the severity of bronchial hyperresponsiveness in asthmatic adults and children [11, 12].
However, its precise mechanisms remain unclear. Recently, KonNo et al. [13] showed that roxithromycin inhibited cytokine expression in peripheral mononuclear cells. We showed that erythromycin and clarithromycin suppress the expression of a pro-inflammatory cytokine interleukin (IL)-6 in human bronchial epithelial cells in vitro [14]. These effects may have some relevance to the beneficial effect seen in the treatment with macrolides.

The purpose of the present study was to determine whether or not erythromycin and its fourteen-member analogue, clarithromycin, suppress ET-1 expression and release in human airway epithelial cells, and to compare their potency with other antiasthma drugs including theophylline, $\beta$-agonist salbutamol, a glucocorticosteroid dexamethasone, and a potent macrolide immunosuppressant, FK506 [15].

\section{Materials and methods}

The study was planned according to the ethical guidelines following the declaration of Helsinki and given the institutional approval, and an informed consent was obtained from each patient. 


\section{Preparation of normal human bronchoepithelial cells}

Normal human bronchial epithelial cells were prepared by the method reported previously [8, 16, 17]. Briefly, a piece of macroscopically and microscopically normal human lobe or segmental bronchus (about $7 \mathrm{~mm}$ in width) was obtained either at the time of lung tumour resection or on autopsy. The bronchus was rinsed in sterile Hanks' balanced salt solution (HBSS) (GIBCO, Grand Island, NY) without calcium and magnesium and incubated in Ham's F12 medium (GIBCO) containing $0.1 \%$ protease (Sigma Chemical Co., St. Louis, MO) at $4^{\circ} \mathrm{C}$ overnight. The bronchus was rinsed with Ham's F12 medium supplemented with $10 \%$ foetal calf serum (FCS; heat inactivated, GIBCO), and the recovered cells were washed twice in HBSS. The number of cells was counted using a standard haemocytometer, and the cell viability was assessed by trypan blue dye exclusion technique.

\section{Culture of bronchial epithelial cells}

The cells were placed on to collagen-coated 24-well flat-bottom tissue culture plates (Koken, Tokyo, Japan) at a density of $5 \times 10^{4}$ cells $\cdot$ well-1 in hormonally defined Ham's F12 medium (HD-F12) as reported previously [8, 16, 17]. HD-F12 contained $1 \%$ penicillin-streptomycin, $5 \mu \mathrm{g} \cdot \mathrm{mL}^{-1}$ insulin (GIBCO), $5 \mu \mathrm{g} \cdot \mathrm{mL}^{-1}$ transferrin (GIBCO), $25 \mathrm{ng}$. $\mathrm{mL}^{-1}$ epidermal growth factor (Collaborative Research Corp., Lexington, MA), $15 \mu \mathrm{g} \cdot \mathrm{mL}^{-1}$ endothelial cell growth supplement (Collaborative Research Corp.), $2 \times 10^{-10} \mathrm{M}$ triiodothyronin (GIBCO), and 10-7 M hydrocortisone (GIBCO). The cells were incubated in a humidified atmosphere at $37^{\circ} \mathrm{C}$ and $5 \% \mathrm{CO}_{2}$. The medium was changed on day 1 and then every 2 days. Confluent monolayers of epithelial cells were stained with anti-keratin (KL-1, Immunotech, Marseille, France) or anti-vimentin (DAKO-Vimentin, DAKOPatts, Glostrup, Denmark), or with control immunoglobulin-G1 (IgG1) monoclonal antibodies using the avidin-biotin complex method $[8,18]$. We used primary and secondary passaged cells for the experiments. In all preparations of primary and secondary passaged bronchial epithelial cells, no less than $98 \%$ of the cells were positive to keratin, but negative to vimentin, indicating that the cells were of epithelial cell origin as described [8, 18].

The human transformed bronchoepithelial BEAS-2B cell line [19] (a kind gift from J.F. Lechner and C.C. Harris, National Cancer Institute, Bethesda, MA) was cultured in HD-F12 as reported previously [17].
Isolation of airway epithelial cells from patients with chronic, stable bronchial asthma, and effect of the drugs on ET-1 expression and release from these cells

To assess the effect of macrolide antibiotics on ET-1 production by inflamed airway epithelium, bronchial epithelial cells were obtained from eight Japanese patients with chronic, stable bronchial asthma (table 1) in fibreoptic bronchoscopy as previously reported [20]. All the patients received neither inhaled nor oral corticosteroid treatment for at least 1 month. Eight nonsmoking control subjects with no clinical history of pulmonary disease also underwent bronchoscopy after informed consent was obtained. Briefly, under local anaesthesia, a fibreoptic bronchoscope (Olympus BF-20, Tokyo, Japan) was inserted transorally. A sheath-covered brush was introduced via the sampling channel, and the epithelial surface of bilateral main bronchi was brushed several times. The number of harvested cells was $1.05 \pm 0.65 \times 10^{6}$, and the cell viability was $65 \pm 12 \%$ for the cells from the main bronchi. The cells were plated at a density of $5 \times 10^{4} \cdot \mathrm{mL}^{-1}$ in 48 -well culture plates with hormonally supplemented Ham's F12 media and cultured until confluent as described above. Then, the cells were treated with different drugs, and the supernatants were harvested after $48 \mathrm{~h}$ and stored at $-80^{\circ} \mathrm{C}$ until ass-ayed. In some cases $(n=5)$, the cell pellet was immediately processed for ribonucleic acid (RNA) isolation, as described below.

\section{ET-1 assay}

The specific immunoreactivity for ET-1 in culture supernatants was measured by sandwich enzyme-linked immunosorbent assay (ELISA) kits previously reported by SuzuKI et al. $[8,21]$. Each sample was assayed in duplicate. This assay cross-reacted $<2 \%$ with ET-3 and big-endothelin, but could not distinguish ET-2 from ET-1. Since studies with fast liquid chromatography revealed no detectable ET-2 in the samples as previously reported [8], we designated the immunoreactivity as for ET-1. The sensitivity was $0.2 \mathrm{pg} \cdot \mathrm{mL}^{-1}$, and intra- and interassay variations were $<10 \%$.

Northern blot analysis for ET-1 messenger RNA expression in human bronchial epithelial cells

Northern blot analysis was performed to study the effect of the drugs on ET-1 messenger (m)RNA expression in human bronchial epithelial cells by the method described previously [8]. Briefly, total cellular RNA was extracted by the method of CHOMCZYNSKI and SACCHI [22], and

Table 1. - Clinical characteristics of patients with chronic asthma

\begin{tabular}{|c|c|c|c|c|c|c|c|}
\hline $\begin{array}{l}\text { Patient } \\
\text { no. }\end{array}$ & Age/sex & Smoking & Therapy & $\begin{array}{l}\text { Blood eosinophil } \\
\text { count } \mu \mathrm{L}^{-1}\end{array}$ & $\%$ PEFR & $\% \mathrm{FVC}$ & $\% \mathrm{FEV} 1$ \\
\hline 1 & $40 / \mathrm{M}$ & - & Theophylline, ambroxol & 545 & 78.3 & 98.3 & 76.8 \\
\hline 2 & $32 / \mathrm{M}$ & - & Theophylline, ambroxol & 876 & 65.7 & 101.9 & 65.8 \\
\hline 3 & $49 / \mathrm{F}$ & - & Ambroxol & 123 & 68.6 & 87.7 & 78.9 \\
\hline 4 & $67 / \mathrm{M}$ & - & Carbocisteine & 890 & 89.5 & 76.2 & 68.7 \\
\hline 5 & $64 / F$ & - & Theophylline, carbocisteine & 254 & 55.7 & 76.0 & 70.8 \\
\hline 6 & $28 / \mathrm{M}$ & - & None & 660 & 49.7 & 77.9 & 67.6 \\
\hline 7 & $33 / \mathrm{F}$ & - & Bromhexine hydrochloride & 465 & 45.7 & 67.8 & 80.9 \\
\hline 8 & $45 / \mathrm{M}$ & exsmoker & None & 776 & 67.5 & 89.9 & 70.5 \\
\hline
\end{tabular}

-: never smoked. PEFR: peak expiratory flow rate; FVC: forced vital capacity; FEV1: forced expiratory volume in one second; M: male; F: female. 
electrophoresed on formaldehyde denatured agarose gel $\left(10 \mu \mathrm{g} \cdot\right.$ lane $\left.^{-1}\right)$ followed by capillary transfer onto Biodyne nylon membrane. The RNA integrity and equivalency of loading were routinely evaluated by ethidium bromide fluorescence. The EcoRI fragment of human preproendothelin-1 complementary deoxyribonucleic acid (cDNA) clone (phET91, the vector is pUC118) [23] was labelled with digoxigenin by random priming (DNA Labelling Kit, Boehringer Mannheim GmbH, Mannheim, Germany) and hybridized with blots followed by enzymatic reaction (DIG Luminescent Detection Kit, Boehringer). Briefly, blots were baked, prehybridized, and hybridized with digoxigeninlabelled cDNA at $42^{\circ} \mathrm{C}$ overnight and then washed at appropriate stringency. After incubation in blocking solution for $1 \mathrm{~h}$, the membrane was incubated with alkaline phosphatase-conjugated anti-digoxigenin antibody for $30 \mathrm{~min}$.

After washing twice, 3-(2'-spiradamantane)-4-methoxy4-(3'-phosphorylaxy)phenyl-1,2-dioxetane disodium salt (AMPPD) was added as a substrate for alkaline phosphatase to detect signals by chemiluminescence on Kodak X-ray film. As an internal control, $\beta$-actin mRNA transcripts were evaluated with a $\beta$-actin cDNA probe (pHF $\beta$ A-1) $[8,24]$.

\section{Preparation of antimicrobial and antiasthmatic drugs}

Erythromycin, clarithromycin, josamycin, tetracyclin (generous gifts from S. Ohmura, Kitasato Institute, Tokyo, Japan) and dexamethasone (Banyu Phamaceutical Ltd, Tokyo, Japan) were solubilized in ethanol as stock solutions and diluted in saline for experiments. Preliminary experiments showed that the final concentrations of ethanol used in the experiments had no significant effect on cell viability, as assessed by the trypan blue dye exclusion technique and on ET-1 release (data not shown). Aminobenzyl penicillin, cefazolin, theophylline, salbutamol and FK506 (a kind gift from Fujisawa Pharmaceuticals, Tokyo) were solubilized in saline and diluted for further experiments.

\section{Statistics}

The results were analysed by nonparametric equivalents of analysis of variance (ANOVA) as reported previously [8]. For evaluating the correlation between ET-1 release and pulmonary function data, a Pearson correlation analysis was used.

Table 2. - Production of immunoreactive endothelin (ET)1 by human bronchial epithelial cells

\begin{tabular}{llcc}
\hline & \multicolumn{3}{c}{$\begin{array}{c}\text { Normal primary } \\
\text { passage bronchial } \\
\text { epithelial cells }\end{array}$} \\
& \multicolumn{3}{c}{ BEAS-2B } \\
\hline Baseline & $74.0 \pm 6.87$ & $80.4 \pm 10.2$ \\
+ cycloheximide & $10 \mathrm{\mu g} \cdot \mathrm{mL}^{-1}$ & $12.0 \pm 12.0^{+}$ & $9.0 \pm 3.90^{+}$ \\
$+\mathrm{IL}-1 \alpha$ & $1 \mathrm{ng} \cdot \mathrm{mL}^{-1}$ & $89.9 \pm 2.00^{+}$ & $120.0 \pm 12.0^{+}$ \\
& $10 \mathrm{ng} \cdot \mathrm{mL}^{-1}$ & $129.0 \pm 31.0^{+}$ & $145.0 \pm 23.7^{+}$ \\
$+\mathrm{IL}-1 \beta$ & $1 \mathrm{ng} \cdot \mathrm{mL}^{-1}$ & $79.6 \pm 12.9$ & $109.0 \pm 23.9$ \\
& $10 \mathrm{ng} \cdot \mathrm{mL}^{-1}$ & $130.0 \pm 12.5^{+}$ & $178.0 \pm 34.9^{+}$ \\
$+\mathrm{TNF}-\alpha$ & $1 \mathrm{U} \cdot \mathrm{mL}^{-1}$ & $100.0 \pm 14.1^{+}$ & $98.0 \pm 16.3$ \\
& $10 \mathrm{U} \cdot \mathrm{mL}^{-1}$ & $189.0 \pm 11.0^{+}$ & $134.0 \pm 7.98^{+}$ \\
$+\mathrm{IL}-1 \alpha$ & $10 \mathrm{ng} \cdot \mathrm{mL}^{-1}$ & & \\
+cycloheximide & $10 \mathrm{ng} \cdot \mathrm{mL}^{-1}$ & $34.9 \pm 12.1^{* *}$ & $20.9 \pm 9.99 * *$
\end{tabular}

The data are shown as means \pm sem from three experiments. ${ }^{+}$: $\mathrm{p}<0.01$ as compared with baseline release in each cell type (analysis of variance (ANOVA)). **: $\mathrm{p}<0.01$ as compared with IL-1 $\alpha\left(10 \mathrm{ng} \cdot \mathrm{mL}^{-1}\right)$-stimulated group in each cell type (ANOVA). IL-1: interleukin-1; TNF- $\alpha$ : tumour necrosis factor- $\alpha$.

\section{Results}

Suppressive effect of erythromycin and clarithromycin on ET-1 production by normal and transfer bronchial epithelial cells

As previously reported [8], normal bronchial epithelial cells from surgical specimens obtained as well as transformed human bronchoepithelial cells BEAS-2B cell line constitutively released immunoreactive ET-1, and this process appeared to require protein synthesis, as assessed by the effect of cycloheximide $\left(10 \mu \mathrm{g} \cdot \mathrm{mL}^{-1}\right)$ (table 2$)$. Proinflammatory cytokines such as IL-1 $\alpha$, IL-1 $\beta$ and tumour necrosis factor (TNF)- $\alpha$ stimulated ET-1 release in a dosedependent fashion in both types of cells as reported previously [8] (table 2). Northern blot analysis showed that the epithelial cells expressed constitutive ET-1 mRNA, which
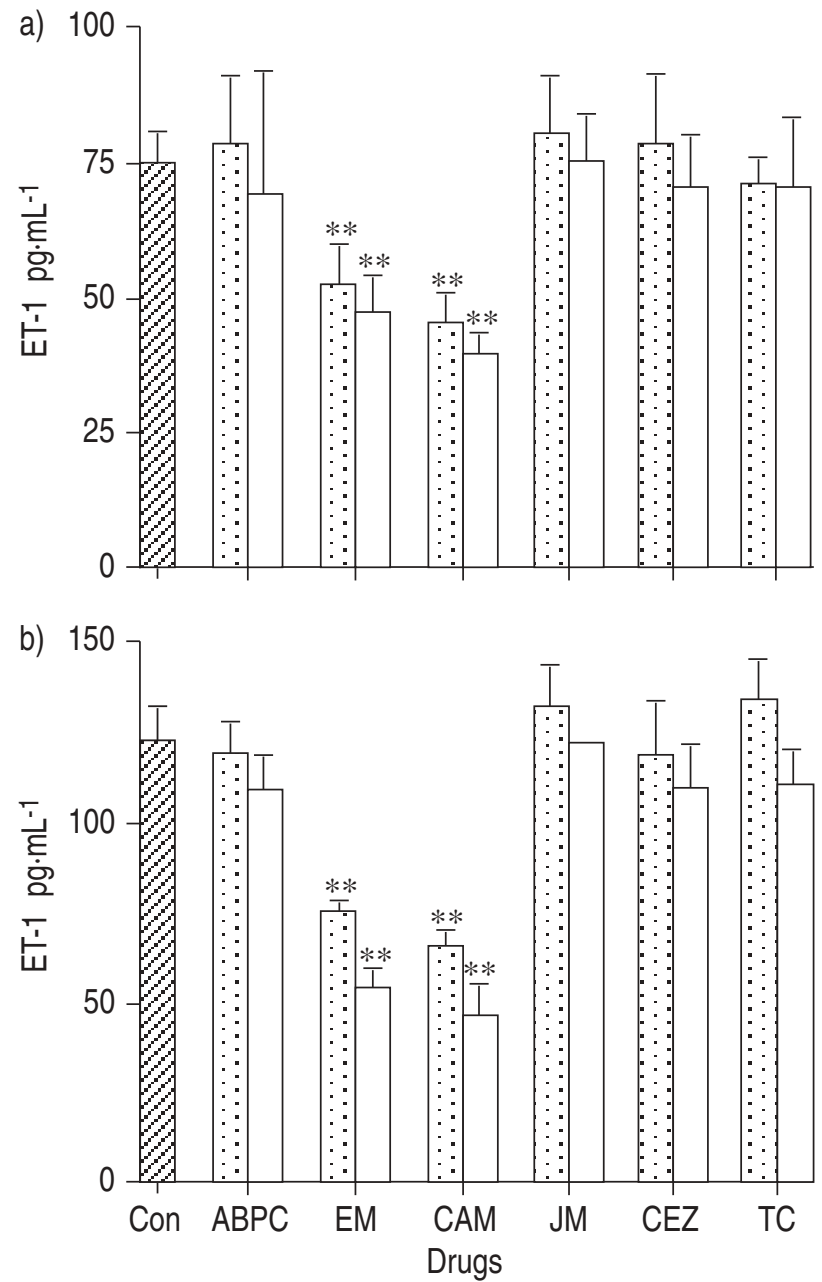

Fig. 1. - Effect of a variety of antimicrobial agents on endothelin (ET)1 production by transformed human bronchial epithelial cells BEAS2B. Erythromycin (EM) and clarithromycin (CAM), but not the other antibiotics, significantly inhibited ET-1 release from human bronchial epithelial cells in culture. a) Effect of antibiotics ( $: 10^{-6}$ and $\square: 10^{-5}$ $\mathrm{M})$ on baseline release of ET-1 after $48 \mathrm{~h}$. b) Effect of antibiotics on ET1 release from interleukin (IL)-1 $\alpha\left(10 \mathrm{ng} \cdot \mathrm{mL}^{-1}\right)$-stimulated bronchial epithelial cells in culture. The antibiotics ( $5:: 10^{-6}$ and $\square: 10^{-5} \mathrm{M}$ ) were added simultaneously with IL-1 $\alpha$, and the supernatants were harvested after $48 \mathrm{~h}$. The data (mean \pm SEM) from three representative experiments, $* *: \mathrm{p}<0.01$ as compared with the controls (analysis of variance (ANOVA)). Con: control; ABPC: aminobenzyl penicillin; JM: josamycin; CEZ: cefazolin; TC: tetracyclin. 
was significantly upregulated by the cytokines listed above [8].

Among the antimicrobial drugs tested, only the fourteen-member macrolides erythromycin and clarithromycin showed any inhibitory action on ET-1 release by unstimulated and stimulated human bronchial epithelial cells BEAS-2B (fig. 1). This was also the case when the cells were pretreated with erythromycin or clarithromycin $12 \mathrm{~h}$ before the treatment of IL-1 stimulation (percentage inhibition at $10^{-6} \mathrm{M}$, erythromycin: $22.5 \pm 5.30 \%$, clarithromycin: $28.5 \pm 2.98 \%)$. Lactate dehydrogenase $(\mathrm{LDH})$ release assay, trypan blue dye exclusion test as well as a colorimetric 3-4,5-(dimethyl-thiazol-2-yl)-2,5-diphenyltetrazolium (MTT) assay [25] revealed that this effect was not due to cytotoxicity (data not shown). Erythromycin and clarithromycin had a dose-dependent inhibitory effect on ET-1 release by primary, second-passaged bronchoepithelial cells as well as BEAS-2B cells (table 3 ). Northern blot analysis showed that both drugs, but not aminobenzyl penicillin, cefazolin, or a sixteen-member macrolide josamycin, inhibited the steady-state levels of ET-1 mRNA in IL-1 $\alpha$ (10 $\mathrm{ng} \cdot \mathrm{mL}^{-1}$ )-stimulated BEAS-2B cells (fig. 2). Erythromycin and clarithromycin had a dose-dependent inhibitory action on ET-1 mRNA in BEAS-2B cells (fig. 3).

\section{Effect of antiasthma drugs on ET-1 production}

Another potent anti-inflammatory agent, dexamethasone, clearly suppressed ET-1 production in normal cultured bron-chial epithelial cells and in BEAS-2B cells (table 3 and fig. 4). In contrast, neither theophylline nor salbutamol showed any significant effect (fig. 4). A potent macrolide immuno-suppressant, FK506, showed no effect, either (fig. 4).

FK506 or motilin was given to BEAS-2B cells $18 \mathrm{~h}$ before the addition of erythromycin, and the influence of such agents on erythromycin effect was studied $(n=3)$. Neither FK-506 nor motilin revealed any effect (percentage inhibition of ET-1 release: erythromycin $\left(10^{-6} \mathrm{M}\right)$ alone, 25.6 $\pm 10.5 \%$; with FK-506, 27.8 $\pm 7.9 \%$; with motilin, $24.9 \pm 11.3 \%, \mathrm{p}>0.05)$. In addition, theophylline $\left(10^{-4} \mathrm{M}\right)$ and erythromycin $\left(10^{-6} \mathrm{M}\right)$ were simultaneously added to BEAS-2B cells, and the effect on ET-1 release was studied. Theophylline did not show any augmenting effect on erythromycin-induced suppression of ET-1 release (per- centage inhibition: erythromycin alone, $25.9 \pm 3.13 \%$, theophylline+erythromycin, $27.9 \pm 4.50 .3 \%, \mathrm{p}>0.05$ ).

Northern blot analysis was performed to evaluate the effect of these drugs on ET-1 mRNA expression in BEAS2B. Again, dexamethasone alone had a significant inhibitory effect on the IL-1-stimulated steady-state levels of

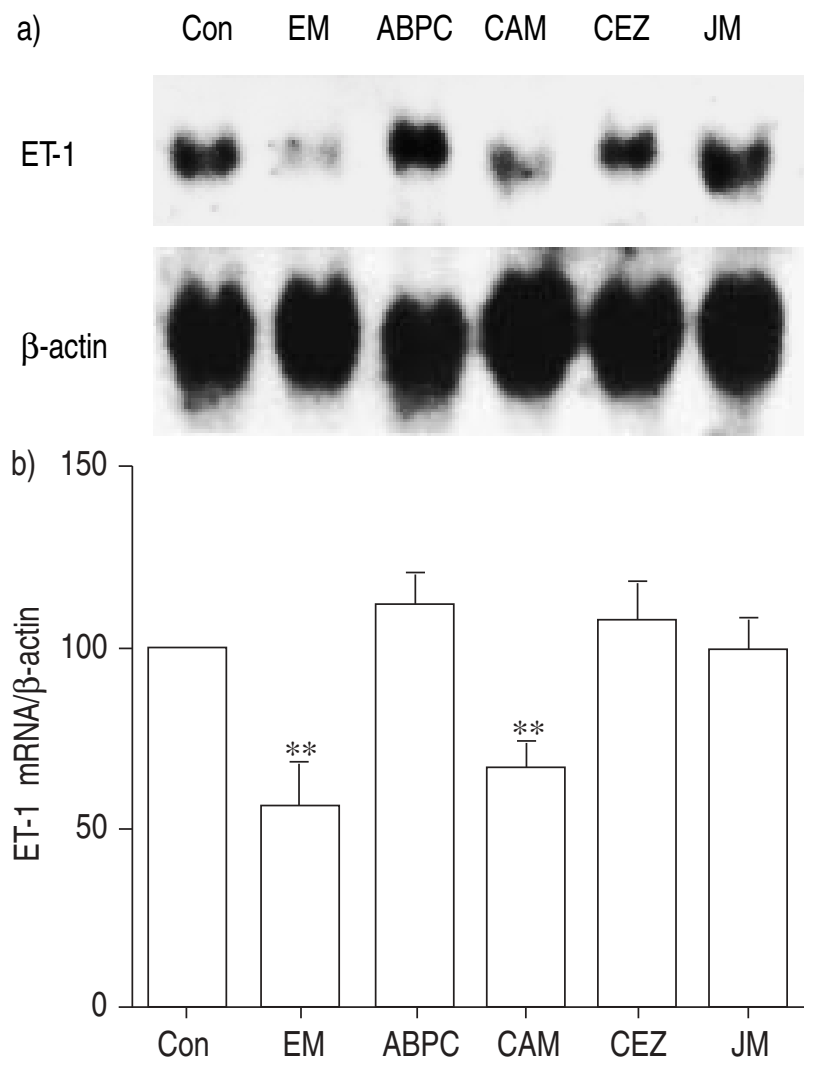

Fig. 2. - a) Northern blot analysis showing effect on erythromycin (EM), clarithromycin (CAM) and the other antibiotics on endothelin (ET)-1 messenger ribonucleic acid (RNA) expression by interleukin-1 $\alpha$ (10 $\left.\mathrm{ng} \cdot \mathrm{mL}^{-1}\right)$-stimulated BEAS-2B cells in culture. The total cellular RNA was extracted $6 \mathrm{~h}$ after treatment and electrophoresed as described in the methods section. EM and CAM, but not aminobenzyl penicillin (ABPC), cefazolin (CEZ) or josamycin (JM) showed an inhibition at 10-5 M. b) Measurement of densitometric signals of ET-1 corrected by actin transcripts showed a significant inhibition by EM and CAM $\left(10^{-5} \mathrm{M}\right)$. **: $\mathrm{p}<0.01$ compared with controls (analysis of variance (ANOVA), $\mathrm{n}=5$ ). Con: control.

Table 3. - Inhibitory effect (\% inhibition) of erythromycin (EM), clarithromycin (CAM), FK506 and dexamethasone on endothelin-1 release by human bronchial epithelial cells

\begin{tabular}{lcccc}
\hline & Concentration & \multicolumn{2}{c}{ Bronchial epithelial cells } & \\
\cline { 2 - 4 } & $\mathrm{M}$ & Normal primary & Normal second passage & BEAS-2B \\
\hline EM & $10^{-7}$ & $21.7 \pm 3.22$ & $24.0 \pm 8.85$ & $24.1 \pm 4.70^{* *}$ \\
& $10^{-6}$ & $26.4 \pm 5.22^{* *}$ & $30.9 \pm 5.02^{* *}$ & $30.4 \pm 9.02^{* *}$ \\
CAM & $10^{-5}$ & $48.4 \pm 4.80^{* *}$ & $38.1 \pm 4.90^{* *}$ & $35.4 \pm 4.42^{* *}$ \\
& $10^{-7}$ & $21.2 \pm 5.67$ & $20.8 \pm 8.52$ & $24.0 \pm 4.78^{* *}$ \\
& $10^{-6}$ & $31.2 \pm 7.45^{* *}$ & $40.4 \pm 8.90^{* *}$ & $33.9 \pm 8.87^{* *}$ \\
FK506 & $10^{-5}$ & $49.0 \pm 5.50^{* *}$ & $37.1 \pm 8.90^{* *}$ & $41.1 \pm 3.98^{* *}$ \\
& $10^{-7}$ & $2.04 \pm 3.24$ & Not tested & Not tested \\
& $10^{-6}$ & $-1.89 \pm 7.05$ & Not tested & Not tested \\
Dexamethasone & $10^{-5}$ & $3.00 \pm 3.90$ & Not tested & Not tested \\
& $10^{-7}$ & $46.6 \pm 0.75^{* *}$ & Not tested & $45.0 \pm 2.90^{* *}$ \\
& $10^{-6}$ & $66.3 \pm 10.3^{* *}$ & Not tested & $65.4 \pm 8.90^{* *}$ \\
& $10^{-5}$ & $75.8 \pm 6.34^{* *}$ & Not tested & Not tested \\
\hline
\end{tabular}

Data are shown as mean \pm SEM. $* *: \mathrm{p}<0.01$ as compared with interleukin (IL)-1 $\alpha$-stimulated control release in each cell type (analysis of variance (ANOVA)). 


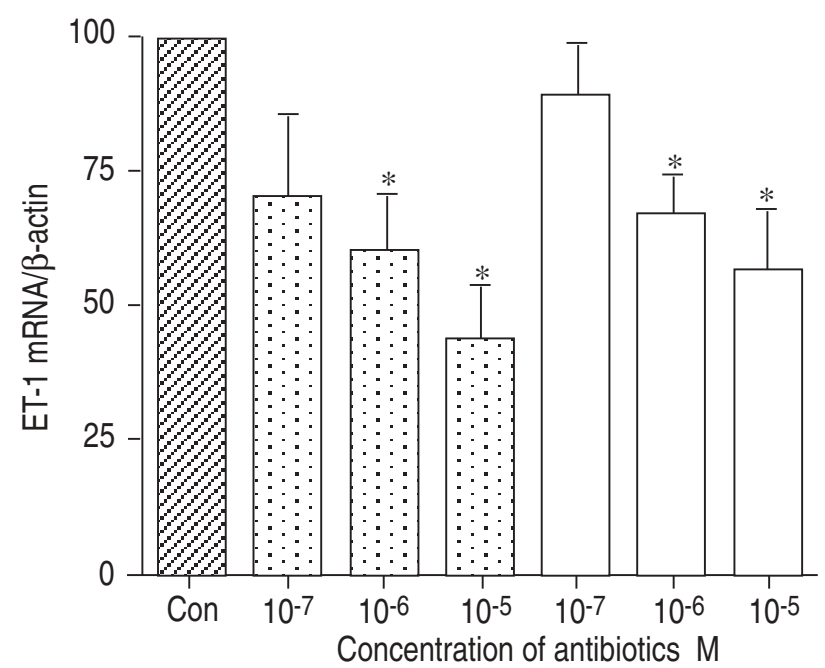

Fig. 3. - Erythromycin (EM; $5:$ ) and clarithromycin (CAM; $\square$ ) showed a dose-dependent inhibitory effect on endothelin (ET)-1 messenger ribonucleic acid (mRNA) levels as assessed by Northern blot analysis. Different concentrations of EM and CAM were added with interleukin- $1 \alpha\left(10 \mathrm{ng} \cdot \mathrm{mL}^{-1}\right)$ to BEAS-2B cells, and the total RNA was extracted as described previously. The data were from four representative experiments. *: $\mathrm{p}<0.05$ compared with control (analysis of variance (ANOVA)). Con: control.

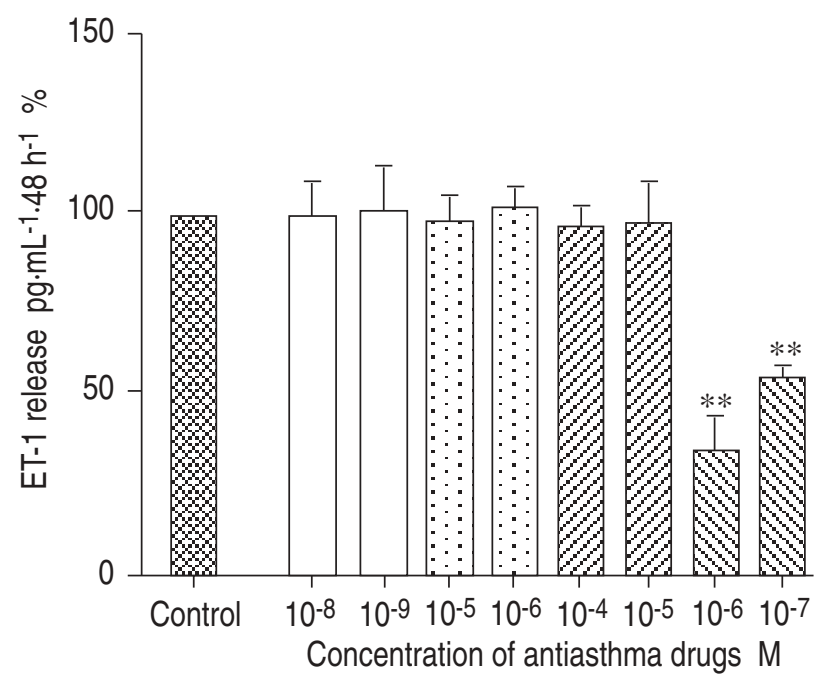

Fig. 4. - Effect of antiasthma drugs on endothelin (ET)-1 release from human bronchial epithelial cell line BEAS-2B. Dexamethasone ( $Q Z)$, theophylline ( $Q$ ), salbutamol ( $:$ : $:$ ) or FK506 ( $\square$ ) were added to the cells simultaneously with interleukin-1 $\alpha\left(10 \mathrm{ng} \cdot \mathrm{mL}^{-1}\right)$, and after $48 \mathrm{~h}$, the supernatants were harvested for ET-1 assay. Dexamethasone, but not theophylline, salbutamol or FK506, showed a significant effect at the therapeutic concentrations. The data are shown as means \pm SEM from three representative experiments. ${ }^{* *}$ : $\mathrm{p}<0.01$ (analysis of variance (ANOVA)).

ET-1 gene expression (percentage inhibition, dexamethasone at $10^{-6} \mathrm{M}, 45.5 \pm 8.95 \%, \mathrm{p}<0.01$, ANOVA). Neither theophylline $\left(10^{-4} \mathrm{M}\right)$, salbutamol $\left(10^{-5} \mathrm{M}\right)$, nor FK506 $\left(10^{-8}\right.$ $\mathrm{M})$ showed any effect (percentage inhibition, theophylline, $0.05 \pm 5.45 \%$, salbutamol, $-3.25 \pm 6.86 \%$, FK506, $2.15 \pm 3.54 \%, \mathrm{p}>0.05$, ANOVA).
Spontaneous release of ET-1 by bronchial epithelial cells from patients with asthma and its relationship to lung functions

Human bronchoepithelial cells were obtained by fibreoptic bronchoscopy from eight patients with mild, stable asthma and eight nonasthmatic control subjects to evaluate ET-1 production. The cells were cultured until confluency, and the spontaneous release of ET-1 was measured. The amount of ET-1 spontaneously released from the primary bronchial epithelial cells of asthma patients was significantly greater than that from those of nonasthmatic subjects (ET-1 from asthmatic epithelial cells: $93.8 \pm 12.2$ $\mathrm{pg} \cdot 48 \mathrm{~h}^{-1}$ in a 48 -well culture plate $(\mathrm{n}=8)$, ET-1 from nonasthmatic epithelial cells: $50.2 \pm 7.1 \mathrm{pg} \cdot 48 \mathrm{~h}^{-1}$ in 48 -well plates $(n=8), p<0.05$, Student's t-test). As shown in figure 5 , the amount of ET-1 spontaneously released for $48 \mathrm{~h}$ showed a significant negative correlation with the most recent value of the percentage peak expiratory flow rate (\%PEFR) in each patient $(n=8)$. ET-1 release did not correlate with the percentage forced expiratory volume in one second (\%FEV1), percentage forced vital capacity (\%FVC), $\mathrm{FEV} 1 / \mathrm{FVC}$ or peripheral blood eosinophil count ( $\mathrm{r}=0.321$, $0.389,0.330$ and $0.332, p>0.05$, respectively).

Suppressive effect of erythromycin and clarithromycin on ET-1 expression and release by bronchial epithelial cells obtained from patients with asthma

The effect of each of the drugs was evaluated after adding the drugs for $48 \mathrm{~h}$. ET-1 protein levels in the supernatants of airway epithelial cells were significantly suppressed with the addition of erythromycin and clarithromycin as well as dexamethasone (percentage inhibition at $10^{-6} \mathrm{M}$, $25.2 \pm 11.2 \%, 32.6 \pm 12.3 \%$ and $34.2 \pm 5.20 \%$, respectively), but not with theophylline (percentage inhibition at $10^{-4} \mathrm{M}$, $0.05 \pm 7.50 \%, \mathrm{p}>0.05$ ) or FK506 (percentage inhibition at $\left.10^{-8} \mathrm{M},-3.25 \pm 6.78 \%, \mathrm{p}>0.05\right)$. Northern blot analysis for

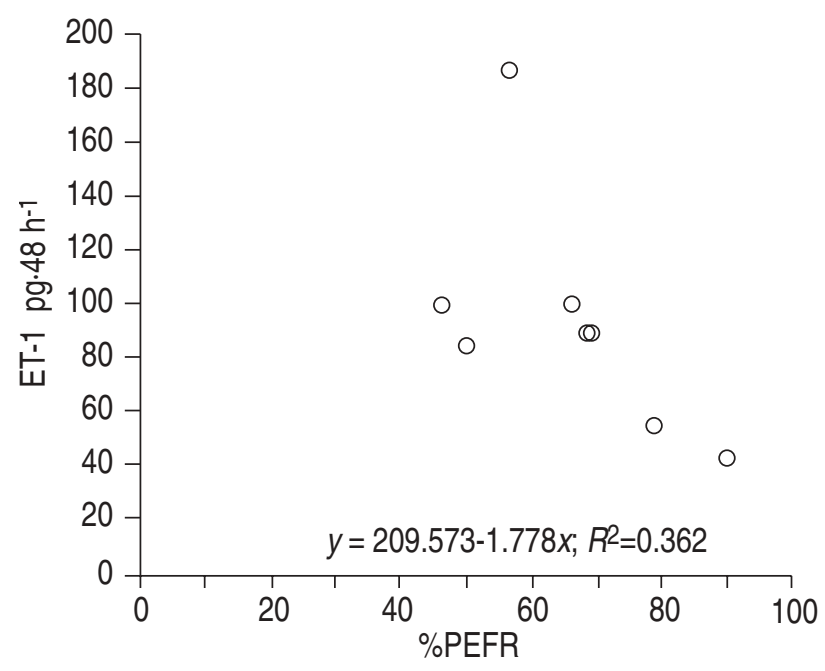

Fig. 5. - Relationship between percentage peak expiratory flow rate (PEFR) and spontaneous release of endothelin (ET)-1 by airway epithelial cells from patients with asthma. The percentage of PEFR was obtained from each patient within a week before bronchoscopic examination. There was a significant negative correlation between the extent of airflow limitation and airway production of ET-1 (Pearson correlation analysis). 
the detection of ET-1 mRNA was performed in five cases, and erythromycin, clarithromycin and dexamethasone showed a suppressive effect on ET-1 mRNA levels (percentage inhibition of ET- $1 / \beta$-actin ratio at $10^{-6} \mathrm{M}, 30.9 \pm 5.30 \%$, $32.1 \pm 7.90 \%$ and $51.9 \pm 13.5 \%$, respectively, $\mathrm{p}<0.01$, ANOVA).

\section{Discussion}

In the present report, we found that fourteen-member macrolide antibiotics uniquely suppressed ET-1 expression and release in human bronchoepithelial cells. A glucocorticosteroid, dexamethasone, also showed a potent inhibitory effect, whereas neither theophylline, salbutamol, nor FK506 had any effect.

ET-1 is one of the important bronchoconstrictors [3]. It causes a strong, persistent constriction in vitro and in vivo. Clinical and experimental studies [3-5] have suggested the importance of this polypeptide in allergic airway inflammation. This polypeptide induces bronchoepithelial cells to release lipoxygenase products [26] and inhibits the proliferation of rat airway epithelial cells [27]. Therefore, ET-1 is one of the modulators of epithelial functions. Appropriate modulation of overproduced ET-1 may, therefore, be one mechanism that leads to the attenuation of airway hyperresponsiveness.

Erythromycin has been shown to be effective for the treatment of asthma in adults [9] and children [10]. In vitro studies showed that these macrolide antibiotics modulate neutrophil migration [28], lymphocyte proliferation [29], and monocyte differentiation [30]. Erythromycin has also been shown to inhibit cytokine release from monocytes [31]. We previously reported that erythromycin and clarithromycin as well as dexamethasone uniquely inhibited IL-6 expression by normal bronchial epithelial cells [14]. In the present study, erythromycin at the range of therapeutic concentration $\left(10^{-6} \mathrm{M}\right)$ reduced ET-1 expression at mRNA as well as at protein levels in human bronchoepithelial cells. This action appeared to be unique because other antibiotics, including sixteen-member macrolide josamycin did not show any effect. We further obtained airway epithelial cells from patients with asthma and studied ET-1 production by these cells. The spontaneous release of ET-1 from airway epithelial cells had a negative correlation with the magnitude of bronchial obstruction (\%PEFR), highlighting a role of ET-1 in the pathogenesis of asthma. It was not clear why the percentage FVC or FEV1 showed no significant correlation with ET-1 release. This might be partially because the abnormalities of study groups were relatively mild (table 1). Erythromycin and clarithromycin as well as dexamethasone, but not theophylline or salbutamol, inhibited ET-1 expression and release from such an inflamed epithelium.

We also studied the effect of antiasthma drugs on ET-1 production. A glucocorticosteroid dexamethasone [32], but not theophylline or salbutamol, inhibited ET-1 release from bronchial epithelial cells. Since theophylline has recently attracted attention for its anti-inflammatory action [33], it would be important to study the combined effect of theophylline and other drugs. In BEAS-2B cells, theophylline did not show any augmenting effect on erythromycininduced ET-1 suppression. FK506, a macrolide immunosuppressant, has been reported to stimulate ET-1 expression in human endothelial cells in vitro [34]. However, this drug showed no effect in the present experiment.

Another important issue would be to elucidate the molecular mechanisms of how these fourteen-member ring macrolides suppressed endothelin-1 expression. Кегсно et al. [29] showed that erythromycin affected the proliferation of peripheral blood lymphocytes at the later stages of signals as compared with FK506, another macrolide agent. Pretreatment with erythromycin did not affect the action of FK506, and, thus, this antibiotic showed its effect via a pathway different from that of FK506. Erythromycin also has a motilin-like stimulating activity on gastrointestinal smooth muscles [35], but neither the gastrointestinal hormone motilin itself nor FK506 had any effect on endothelin-1 release by bronchial epithelial cells in our studies. Recent studies have demonstrated the important roles of transcription factors in endothelin-1 expression [34, 36]. Further studies will be necessary to elucidate the mechanism of erythromycin and clarithromycin effects on transcription rate and degradation of endothelin-1 messenger ribonucleic acid. Characterization of the chemical structure responsible for its potential would also be important to pursue for a possible new type of anti-inflammatory agent in the treatment of asthma.

Acknowledgements: The authors are grateful to K. Yoshida for his cooperation. They also thank A. Hashimoto for her excellent technical support.

\section{References}

1. Yanagisawa M, Masaki T. Molecular biology and biochemistry of the endothelins. Trends Pharmac Sci 1989; 10: 374-378.

2. Uchida $\mathrm{Y}$, Ninomiya M, Sotome M, et al. Endothelin, a novel vasoconstrictor peptide, as potent bronchoconstrictor. Eur J Pharmacol 1988; 154: 227-228.

3. Mattoli S, Soloperto M, Marini M, Fasoli A. Levels of endothelin in the bronchoalveolar lavage fluid of patients with symptomatic asthma and reversible airflow obstruction. J Allergy Clin Immunol 1991; 88: 376-384.

4. Vittoli E, Marini M, Fasoli A, DeFranchis R, Mattoli S. Increased expression of endothelin in bronchial epithelial cells of asthmatic patients and effect of corticosteroids. Am Rev Respir Dis 1992; 146: 1320-1325.

5. Finn F, Ole HS, Theis T, Oddvar N, Torstein L, Geir C. Endothelin production and effects of endothelin antagonism during experimental airway inflammation. Am J Respir Crit Care Med 1997; 155: 1404-1412.

6. Black PN, Ghatei MA, Takahashi K, et al. Formation of endothelin by cultured airway epithelial cells. FEBS Lett 1989; 255: 129-132.

7. Mattoli S, Maurizio M, Riva G, Allegra L, Fasoli A. Specific binding of endothelin to human bronchial smooth muscle cells in culture and secretion of endothelin-like material from bronchial epithelial cells. Am J Respir Cell Mol Biol 1990; 3: 145-151.

8. Nakano J, Takizawa H, Ohtoshi T, et al. Endotoxin and proinflammatory cytokines stimulate expression and release of endothelin-1 in human airway epithelial cells. Clin Exp Allergy 1994; 24: 330-336.

9. Itkin IH, Menzel ML, Denver C. The use of macrolide antibiotic substances in the treatment of asthma. J Allergy 
1970; 45: 146-162.

10. Black PM. The use of macrolides in the treatment of asthma. Eur Respir Rev 1996; 6: 240-243.

11. Miyatake H, Taki F, Taniguchi H, Suzuki R, Takagi K, Satake T. Erythromycin reduces the severity of bronchial hyperresponsiveness in asthma. Chest 1991; 99: 670-673.

12. Shimizu T, Kato M, Mochizuki H, Tokuyama K, Morikawa A, Kuroume T. Roxithromycin reduces the degree of bronchial hyperresponsiveness in children with asthma. Chest 1994; 106: 458-461.

13. Konno S, Asano K, Kurokawa M, Ikeda K, Okamoto K, Adachi M. Antiasthmatic activity of a macrolide antibiotic, roxithromycin: analysis of possible mechanisms in vitro and in vivo. Int Arch Allergy Immunol 1994; 105: 308-316.

14. Takizawa H, Desaki M, Ohtoshi T, et al. Erythromycin suppresses interleukin 6 expression by human bronchial epithelial cells. Biochem Biophys Res Commun 1995; 210: 781-786.

15. Mori A, Suko M, Nishizaki Y, et al. IL-5 production by CD4+ T cells of asthmatic patients is suppressed by glucocorticoids and the immunosuppressants FK506 and cyclosporin A. Int Immunol 1995; 7: 449-457.

16. Takizawa H, Ohtoshi T, Kikutani T, et al. Histamine activates bronchial epithelial cells to release inflammatory cytokines in vitro. Int Arch Allergy Immunol 1995; 108: 260-267.

17. Takizawa $\mathrm{H}$, Ohtoshi $\mathrm{T}$, Ohta $\mathrm{K}$, et al. Interleukin $6 / \mathrm{B}$ cell stimulatory factor- 2 is expressed and released by normal and transformed human bronchial epithelial cells. Biochem Biophys Res Commun 1992; 187: 569-602.

18. Ohtoshi T, Vancheri C, Cox G, Gauldie J, Denburg JA, Jordana M. Monocyte-macrophage differentiation induced by human upper airway epithelial cells. Am J Respir Cell Mol Biol 1991; 4: 255-263.

19. Reddel RR, Ke Y, Gerwin BI, et al. Transformation of human bronchial epithelial cells by infection with SV40 or adenovirus-12/SV 40 hybrid virus, or transfection via strontium phosphate coprecipitation with a plasmid containing SV40 early region genes. Cancer Res 1988; 48: 1904-1909.

20. Kelsen SG, Mardini IA, Zhou S, Benovic JL, Higgins NC. A technique to harvest viable tracheobronchial epithelial cells from living human donors. Am J Respir Cell Mol Biol 1992; 7: 66-72.

21. Suzuki N, Matsumoto M, Kitada C, Masaki T, Fujino M. A sensitive sandwich-enzyme immunoassay for human endothelin. J Immunol Meth 1989; 118: 245-250.

22. Chomczynski D, Sacchi N. Single-step method of RNA isolation by guanidinium thiocyanate-phenol-chloroform extraction. Analyt Biochem 1987; 162: 156-159.

23. Inoue A, Yanagisawa M, Takuwa Y, Mitsui Y, Kobayashi M, Masaki T. The human preproendothelin-1 gene. Com- plete nucleotide sequence and regulation of expression. $J$ Biol Chem 1989; 264: 14954-14959.

24. Gunning P, Ponte P, Okayama H, Engel J, Blau H, Kedes L. Isolation and characterization of full-length cDNA clones for human $\alpha-, \beta$ - and $\gamma$-actin mRNAs: skeletal but not cytoplasmic actins have an amino-terminal cysteine that is subsequently removed. Mol Cell Biol 1983; 3: 787-795.

25. Takizawa H, Ohtoshi T, Ohta K, et al. Growth inhibition of human lung cancer cell lines by interleukin 6 in vitro: a possible role in tumor growth via an autocrine mechanism. Cancer Res 1993; 53: 4175-4181.

26. Wu T, Mullol J, Rieves RD, Logun C, Hausfield J, Kaliner MA, Shelhamer JH. Endothelin-1 stimulates eicosanoid production in cultured human nasal mucosa. Am J Respir Cell Mol Biol 1992; 6: 168-174.

27. Nakaki T, Nakayama M, Yamamoto S, Kato R. Endothelin-mediated stimulation of DNA synthesis in vascular smooth muscle cells. Biochem Biophys Res Commun 1989; 158: 880-883.

28. Nelson S, Summer WR, Terry PB, Warr GA, Jakab GJ. Erythromycin induced suppression of pulmonary antibacterial defences. Am Rev Respir Dis 1987; 136: $1207-$ 1212.

29. Keicho N, Kudoh S, Yotsumoto H, Akagawa KS. Antilymphocytic activity of erythromycin distinct from that of FK506 or cyclosporin A. J Antibiotics 1993; 46: 14061413.

30. Keicho N, Kudoh S, Yotsumoto H, Akagawa KS. Erythromycin promotes monocyte to macrophage differentiation. J Antibiotics 1994; 47: 80-89.

31. Iino Y, Toriyama M, Kudo K, Natori Y, Yuo Y. Erythromycin inhibition of lipopolysaccharide-stimulated tumour necrosis factor-alpha production by human monocytes in vitro. Ann Otol Rhinol Laryngol 1992; 101: 1620.

32. Barnes PJ. Molecular mechanisms of steroid action in asthma. J Allergy Clin Immunol 1996; 97: 159-168.

33. Banner KH, Page CP. Anti-inflammatory effects of theophylline and selective phosphodiesterase inhibitors. Allergol Int 1996; 45: 125-132.

34. Takeda Y, Yoneda T, Ito Y, Miyamori I, Takeda R. Stimulation of endothelin mRNA and secretion in human endothelial cells by FK506. J Cardiovasc Pharm 1993; 22 (Suppl. 8): S310-S312.

35. Kondo Y, Torii K, Omura S, Itoh Z. Erythromycin and its derivatives with motilin-like biological activities inhibit the specific binding of 125 I-motilin to duodenal muscle. Biochem Biophys Res Commun 1988; 150: 877-882.

36. Bandyopadhyay RS, Phelan M, Faller DV. Hypoxia induces AP-1-regulated genes and AP-1 transcription factor binding in human endothelial cells and other cell types. Biochem Biophys Acta 1995; 1262: 72-78. 